\title{
Academic Reading and Writing Needs of Undergraduate Nursing Students in Research
}

\author{
Reynold C. Padagas \\ College of Nursing and Health Sciences, José Rizal University \\ Mandaluyong City, Philippines \\ https://orcid.org/0000-0001-7584-1750 \\ Bonjovi H. Hajan \\ Senior High School Division, José Rizal University \\ Mandaluyong City, Philippines \\ https://orcid.org/0000-0003-2911-5824
}

\begin{abstract}
Like other students of any discipline, nursing students are taught to develop and enhance their cognitive, affective, and psychomotor skills. They are being trained for their future nursing responsibilities in the clinical or community-based facilities and are empowered to create positive changes in healthcare through the conduct and publication of quality research. However, conducting and publishing quality research could be challenging for many nursing students as these entail a myriad of skills, including reading and writing in the discipline. This study investigated students' needs in academic reading and writing in nursing research using sequential-explanatory mixed methods design. Quantitative data were first gathered through a self-administered questionnaire from a group of 18 nursing students. Afterward, six conveniently selected students from the same group were subjected to a semi-structured interview conducted online. Descriptive statistics such as Mean and Standard Deviation and content analysis were employed as data analyses for the survey and interview data. The following are the findings of the study: (1) on academic reading, nursing students' needs include organizing literature items reviewed, and synthesizing general concepts to generate a new idea; and (2) on academic writing, students' needs encompass the use of correct grammar, paraphrasing, adherence to a publication format, and confidence in academic writing. The study draws pedagogical implications for an English for Academic Purposes (EAP) classroom, suggesting that language teachers employ explicit teaching of reading strategies that facilitate critical reading and teach academic writing both at the micro and macro levels.
\end{abstract}

Keywords: academic reading and writing; undergraduate nursing research; English for academic purposes 


\section{Introduction}

Institutions of higher learning have a time-old threefold function, and these include research, instruction, and extension (Tanhueco-Tumapon, 2016). Considering this, research is regarded as the core that bridges the gaps in both the academic and community purposes of higher education institutions. Research is elemental in any learning institution as it creates a secure interconnection between and among the goals of higher learning. It is one of the fundamental metrics of quality education in higher learning institutions like the university. It is perhaps safe to assume that an institution without quality research production and publication may be a clear manifestation of a lack of support for higher learning.

Disseminating new scientific knowledge through publication is crucial in any discipline, including nursing (Yancey, 2016). Nursing students are trained to develop and enhance their cognitive, affective, and psychomotor skills. The formal training of nursing students is not only limited to their future promotive, preventive, curative, and rehabilitative duties in the clinical or public nursing facilities. It also includes an aspect that fosters healthcare development through active involvement in the writing and publishing of scientific research. Preparing undergraduate nursing students to become researchers is a faculty requirement (Parilo, Parsh \& Samson, 2019). The need to improve nursing students' research skills is essential as it contributes to the science of nursing, specifically evidencebased nursing (Ryan, 2016). However, critical reading as an essential skill in research could be difficult to maneuver (Gile, 2001). Also, writing has remained "a game with a bewildering set of rules, many of which are never made explicit to student writers" (Harwood \& Hadley, 2004: 356).

Building on this contention, this study is an attempt made to provide insights into the needs of nursing students concerning academic reading and writing in research. The researchers believe that skills in reading and writing applied in academic settings are extremely pivotal in nursing research as these serve as pathways for nursing students to engage in research and demonstrate scholarship essential for evidence-based practice in healthcare and nursing. The findings of the present study have useful applications to the EAP pedagogy, particularly in the context of academic reading and writing in nursing research.

\subsection{Literature Review}

\subsubsection{Academic Reading and Writing}

Academic reading is defined as "purposeful and critical reading of lengthy academic texts for studying specific major subject areas" (Sengupta, 2002: 3). It is a concentrated reading and is distinct from daily reading (Faizah, 2004). The ability to comprehend academic writings is vital, which the university students are required to perform (Levine, Ferenz \& Reves, 2000). In the context of research, academic reading may be regarded as critical reading. Gile (2001) identified three norms for critical reading: a research act subject to the similar patterns as other research acts, the importance of comprehending before evaluating, and skepticism towards one's evaluation. Critical reading as a research act subject pertains to its role in ascertaining systematic, rigorous, careful, and objective reading. Comprehension before evaluation suggests that the reader must 
understand the writer's positions and opinions embedded in his or her writing. This is important to ensure that misperceptions about the veracity of the literature are avoided. Finally, skepticism towards one's evaluation signifies a careful process of reading to avoid reader bias. A thorough reading of all parts of the material and double-checking are essential features of this norm.

Given these norms, academic reading in research has direct applications in the literature review because, in many cases, the literature reading stage is not appropriately undertaken (Gile, 2001). As Gile (2001: 1) asserted, one reason could be attributed to the critical reader's behavior, "who may be careless, impatient, or lack the stamina required for long, careful reading." In connection, critical reading entails genre knowledge. According to Carrell (1985), students who are taught using genre structure tend to develop better reading recall and/or comprehension. This is also consistent with Hyon (2001), who discovered that an EAP genre-based reading pedagogy resulted in students' more considerable attention to rhetorical features in texts.

The notion of "academic writing" is frequently construed in a slightly unreflective approach leading to the existence of its various definitions (Ask, 2007, as cited in Borglin \& Fagerström, 2012). Grami (2010: 9) describes academic writing as a sophisticated writing type that entails, "careful thought, discipline, and concentration." It is that type of writing that makes use of linguistic devices held as an academic language (Schleppegrell, 2012). However, an academic language may be better viewed from different disciplinary perspectives because, according to Hyland and Tse (2007), each field of study shares its own bundle of lexical terms and structures. In connection, academic writing requires genre knowledge since genre commands certain rhetorical devices needed in a specific discipline (Bhatia, 1993). In a nutshell, academic writing involves knowledge of conventions, styles, language, and audience given a specific area of discipline (Hyland, 2003), and successful academic writing situates "complex higher-order analytical demands" on learners (Whitehead, 2002: 502). In research, effective academic writing entails a certain level of awareness and understanding and, more importantly, the ability to critically evaluate and integrate ideas and correctly build on and reference to the body of knowledge (Knowles \& McGloin, 2007).

Given the nature of academic reading and writing espoused above, it can be argued that these skillsets are essential for conducting proper research that results in publication. Academic reading is necessary to critically examine the existing body of knowledge, which could pave the way for the development of academic writing skills, which is central for writing and publishing research outputs in nursing.

\subsubsection{Some Studies on Academic Reading and Writing in Nursing}

Research into academic reading and writing in the context of nursing have been proliferating recently. For example, Gazza and Hunker (2012) determined scholarly writing problems in post-licensure nursing students that needed teachers to respond to a variety of writing abilities. To improve writer development, they offered scaffolding within and across courses in the nursing 
program and also in courses that promote the nursing curriculum. The authors also responded to the call for faculty training to facilitate successful scaffolding. Moreover, Uysal Toraman, Hamaratçılar, Tülü and Erkin (2017) investigated the effectiveness of writing an undergraduate thesis on the behaviors of nursing learners with respect to research and advancement in nursing. The research suggested that writing a nursing education thesis has a favorable impact on nursing students' behaviors towards and understanding of research and advancement in nursing. Additionally, Miller, Russell, Cheng, and Zembles (2018) studied the usefulness of a scaffolded pedagogy in writing with virtual degreeaccomplishment nursing learners. The study concluded that writing should be taught with devoted time in the nursing classes for learners to develop as skilled writers. It should provide authentic exposure that will enable them to conceptualize as well as present their thoughts in a meaningful and critical manner.

Furthermore, Shellenbarger, Gazza, and Hunker's (2018) study determined perceived skills of undergraduate nursing learners in showcasing the scholarly writing competence. Their results showed that the students perceived they understand the necessary elements of scholarly writing. Besides, the study found that students sometimes employed preliminary activities which included preparing an outline, thinking, find the literature, devoting time conceptualizing, writing in small parts to scaffold their writing, constructing scholarly writing following recognized project formats, among others.

In the Philippines, research and development is an integral component of the Science, Technology, Engineering, Agri-Fisheries, and Mathematics (STEAM) program in higher education (Anito \& Morales, 2019). Universities should establish a research organization that supports the development of research competence among their research stakeholders (Anito, Limjap \& Padagas, 2020). Particularly, nursing graduates are expected to participate in health-related research, evaluate research projects, and utilize the research process in improving client care (Commission on Higher Education, 2017). Through courses on disciplinary research, nursing students are assumed to communicate effectively using culturally appropriate language; and conduct research with an experienced researcher that contributes to the development of practice in healthcare and nursing. The journey in nursing research, however, is not learned overnight. As a result, many strategic interventions have been established to help nursing students in their research work. These interventions include internship other than the collective didactic and classroom learning experience in research writing. According to O'Brien and Hathaway (2018), an internship is a favorable practice that not only provides significant practical skills but also helps stimulate curiosity in a prospective research profession.

Interestingly, O'Brien and Hathaway (2018) also expressed that teachers carrying out research projects seldom interact with nursing learners in undergraduate courses. The workshop strategy is useful for training nurses to write publishable articles and for developing the writing abilities of nurses and nursing learners; however, such method, to be effective, should work hand in hand with individual 
monitoring and feedback on writing (Derouin et al., 2015). In another study, attributional retraining (AR) was instituted to improve students' writing performance (Tai, Pan \& Lee, 2016). Moreover, the development and the durability of research allow for the marked appearance of discipline in nursing sciences (Szyba et al., 2018). Issues and concerns in research writing also include facilitation styles employed by the teacher and academic integrity held by students. In a nursing research class with diverse learners, a teacher needs to ensure class facilitation to fulfill course objectives. While the study was related to the class facilitation in a hard science course, the lessons uncovered from the findings of Padagas (2020) emphasized the role of facilitation techniques in maximizing collaborative learning activities despite team diversity. A supportive intervention facilitation style is deemed necessary because writing skills can thrive among nontraditional undergraduate students when scaffolded with guided instruction (Miller, Russell, Cheng \& Skarbek, 2015). Besides, Gutierrez and Padagas (2019) examined academic dishonesty among college nursing students. Their findings revealed that while there is no single measure to prevent or resolve academic dishonesty in college students, teachers and the school play a crucial role in helping students live with academic integrity.

Ostensibly, writing research in nursing requires tedious preparations for one to be able to master it. More than the pieces of training embedded in instructional designs that are translated into teaching and learning processes in nursing research is the necessity to publish in reputable journals, both those in print and pixels. However, research publication entails a myriad of skills, including critical analysis of the literature and advanced academic writing. These are much debated as the culprit as to why student researchers fail to publish their academic works because academic writing is perhaps the most critical factor in showcasing scholarship (Whitehead, 2002). Notwithstanding its central value, research on writing within the context of nursing students indicates that academic reading and writing remains as one of the most challenging facets of their learning (Whitehead, 2002).

All the studies mentioned above underscore the importance of academic literacy skills such as reading and writing in nursing education. However, it is noteworthy that none of these studies has explored the needs of nursing students with respect to academic reading and writing, especially in the research context. The researchers believe that skills in reading and writing applied in academic contexts are extremely pivotal in nursing research as these serve as pathways for nursing students to engage in research and demonstrate scholarship essential for evidence-based practice in healthcare and nursing.

This study investigated the academic reading and writing needs of undergraduate nursing students in research. Specifically, this research aimed to address the following questions:

1. What are the academic reading needs of nursing students in a research class?

2. What are the academic writing needs of nursing students? 


\section{Methods}

\subsection{Research Design}

This study applied the sequential-explanatory mixed methods research design by Creswell and Plano-Clark (2011). The use of such design was applicable in the present study because quantitative data collection and analysis preceded the qualitative phase (see Figure 1). Besides, the emphasis of the study was maintained since a more in-depth investigation was carried out to build on the quantitative data results (Creswell \& Plano-Clark, 2011). However, it should be noted that the qualitative phase may be limited. It only considered responses from the six participants who were conveniently available to take part in its conduct.

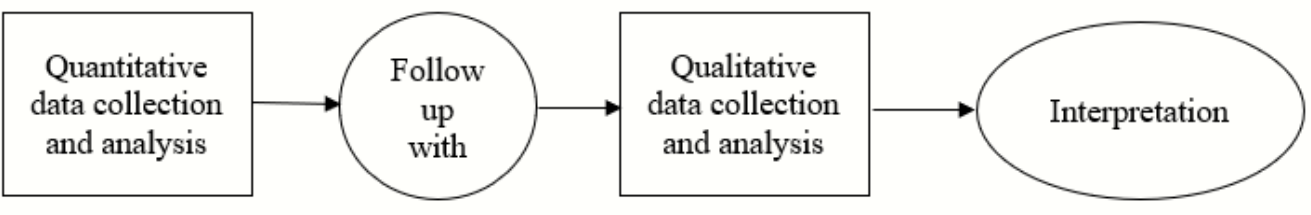

Figure 1: Sequential-explanatory research design flow (Creswell \& Plano-Clark, 2011)

\subsection{Participants}

The participants of this research were undergraduate nursing students in a private university in Mandaluyong City, Philippines. For the quantitative strand of the study, the researchers used an entire class comprising of 18 fourth-year nursing students (6 male and 12 female) whose age bracket ranged from 20-40. These students could be considered bilingual since English is treated as a medium of instruction in the Philippines (Wa-Mbaleka, 2014). They were purposively selected as the participants because they were enrolled in a nursing research class and had already completed research projects on clinical and community nursing. The researchers believed that these students could best share their challenges (needs) regarding academic reading and writing.

For the qualitative strand, the researchers employed a convenience sampling technique in which six students from the same group participated in the qualitative interview. It should be noted that the qualitative phase occurred after the semester had ended in which some students were no longer available for interviews during this time; hence, the employment of convenience sampling.

\subsection{Instruments}

After reviewing extant literature on academic reading and writing, the researchers developed a survey questionnaire to assess the academic reading and writing needs of the participants. The questionnaire consisted of two parts. Part 1 measures the academic reading needs and part 2 assesses the academic writing needs. The instrument was a Likert scale characterized with a four-point scaling (refer to Table 1 for the scaling and its verbal interpretations). The verbal interpretations were based on Akcaoğlu's (2011) study, which assessed the needs of graduate students in terms of academic writing. The original version had "no need" as the last level comprising of five levels all in all. For this study's purpose, only four levels were retained since the researchers opted to use a four-point scaling. The range was calculated by $(4-1=3)$ then divided by four as it is the 
highest value of the scale $(3 \div 4=0.75)$. This became the basis of the arbitrary scores necessary to interpret the weighted means (WM). As a justification, Borgers, Sikkel, and Hox (2004), as cited by Leung (2011), suggested using four points as an ideal after recognizing several choices, the neutral point, and reliability. Meanwhile, using the arbitrary scores, the researchers created corresponding verbal interpretation (VI) adapted from Akcaoğlu (2011) for each range, as presented in Table 1.

Table 1: Arbitrary Score and Its Corresponding Verbal Interpretation (VI)

\begin{tabular}{|c|c|}
\hline WM range & VI \\
\hline $3.26-4.00$ & Low \\
\hline $2.51-3.25$ & Moderate \\
\hline $1.76-2.50$ & High \\
\hline $1.00-1.75$ & Very high \\
\hline
\end{tabular}

Initially, there were eight items in each part of the questionnaire. These items were checked for face and content validity. The questionnaire's validation was done by a panel of experts from the English Language and Nursing fields. The number of items in the instrument was increased to 10 for each component after the validation. There were also modifications in the language components of the items that were considered vague. After the validation, the instrument was pilot tested among 15 students, and the result yielded a Cronbach's alpha of 0.82, suggesting that items were internally consistent. For the qualitative strand, the researchers focused on two questions regarding students' needs in academic reading and academic writing. The questions also underwent validation by the same panel of experts. The survey was administered as a self-completion questionnaire. Moreover, the participants were given one hour to complete it. The qualitative interview was of a semi-structured type, conducted among the participants through online. An example of a question that was asked to the participants during the semi-structured interview was, "What challenges about reading and writing did you encounter in your research class?".

\subsection{Data Analysis}

The quantitative data were processed using descriptive statistics. Explicitly, Mean Score (MS) and Standard Deviation (SD) were calculated on the individual items of the academic reading and writing needs survey. Weighted Mean (WS) was also determined to provide an overall measure of students' academic reading and writing needs. To determine students' academic reading and writing needs, verbal interpretations of the acquired MS and the WS, which can be found in Table 1 , were used. Meanwhile, content analysis was performed for the qualitative data. The contents in which the qualitative analysis anchored were on the two variables investigated in this study. This was done so because the qualitative findings were used as supplements to the quantitative results. 


\subsection{Ethical Considerations}

The Jose Rizal University Research Ethics Committee allowed the conduct of the study. Also, individual informed consent was acquired from the students. The participants were ensured of anonymity and confidentiality of personal information. To establish rigor on the acquired qualitative data from written interviews, the researchers treated the data free from partialities and students were consulted with their responses to ensure authenticity and reliability of the analysis.

\section{Results}

\subsection{Academic Reading Needs of Nursing Students in Research}

Table 2 presents the quantitative results on students' academic reading needs. It can be gleaned that the nursing students' academic reading needs in a research class are moderate (WM: 3.13). Among the items in this skills set, Item Number 1 that says "I use journal articles during the literature review because they are highly reliable" (MS: 3.56; SD: 0.60) got the highest mean score followed by Item Number 9, which states "I consider time element in conducting the literature review" (MS: 3.33; SD: 0.94). The lowest mean scores are Item Numbers 7 and 8 that stated: "I am organized in conducting the literature review" (MS: 2.78; SD: 0.97 ) and "I am capable of synthesizing general concepts to generate a new idea" (MS: 2.72; SD: 0.87), respectively.

Table 2: Academic Reading Needs of Nursing Students

\begin{tabular}{|c|c|c|c|}
\hline Items & MS & SD & VI \\
\hline $\begin{array}{l}\text { 1. I create a comprehensive plan for the literature } \\
\text { review. }\end{array}$ & 3.22 & 0.92 & Moderate \\
\hline $\begin{array}{l}2 . \quad \text { I use journal articles during the literature review } \\
\text { because they are highly reliable. }\end{array}$ & 3.56 & 0.60 & Low \\
\hline $\begin{array}{l}\text { 3. I understand primary and secondary sources in } \\
\text { literature review. }\end{array}$ & 3.11 & 0.87 & Moderate \\
\hline $\begin{array}{l}\text { 4. I am techno-intelligent to search using the online } \\
\text { platforms. }\end{array}$ & 3.06 & 0.85 & Moderate \\
\hline $\begin{array}{l}\text { 5. I read the entire articles from various sources to look } \\
\text { for the most important information to be retrieved. }\end{array}$ & 3.17 & 0.60 & Moderate \\
\hline $\begin{array}{l}\text { 6. I need to broaden my skill in literature search using } \\
\text { specific and topic-related concepts. }\end{array}$ & 3.28 & 0.93 & Moderate \\
\hline 7. I am organized in conducting the literature review. & 2.78 & 0.97 & Moderate \\
\hline $\begin{array}{l}\text { 8. I am capable to synthesize general concepts to } \\
\text { generate a new idea. }\end{array}$ & 2.72 & 0.87 & Moderate \\
\hline $\begin{array}{l}\text { 9. I consider time element in conducting the literature } \\
\text { review. }\end{array}$ & 3.33 & 0.94 & Low \\
\hline $\begin{array}{l}\text { 10. I construct conclusion based on the information } \\
\text { obtained. }\end{array}$ & 3.06 & 0.83 & Moderate \\
\hline Weighted Mean & 3.13 & 0.84 & Moderate \\
\hline
\end{tabular}


Remarkably, the quantitative result above shows that while nursing students' needs are moderate in terms of academic reading, they may need further support concerning organizing and synthesizing literature. This is indicated by the lowest mean scores obtained in Items 8 and 7, as discussed above. The qualitative findings could further explain such a result asked during the interview. Below are the extracts exemplifying this confirmation.

We needed to enhance our analyzation [analytical] technique in order to create good interpretation [of the literature examined]. (NS1)

I haven't much struggle with this since I can access a lot of paper which includes some concept from our study too. However, given there are too many studies, I've had a hard time selecting which is really necessary and [which is not] not. (NS2)

In our case, since it was a timeless worldwide problem, there are a lot of researchers who conducted a similar study or at least a close one. Here comes the most complicated thing for us. How do we sort out those literature? Given that, it is a lot. It almost feel[s] like doing a puzzle and it was overwhelming. (NS5)

From the extracts above, it is apparent that students find it challenging to organize and synthesize the literature that they read about their studies. NS1 illustrates this by stating that excellent analytical skills are a must to examine the relevance of the works examined critically. This is also reiterated in NS2's statement that choosing the most relevant literature could be challenging, whereas NS5 underscores how doing literature review could be overwhelming with all the information presented and that the real challenge is to organize them into something that would make sense. Besides organizing and synthesizing literature, students also find it challenging to locate information appropriate to their studies. The statements below from students affirm such findings.

I think the biggest challenges we encountered during finding literature review, are finding up to date researches which are researches from 2014 to present and give interpretation for it. (NS1)

Hunting for a good related literature is challenging because you have to find an equal or significant source[s] or ideas that is [are] logical with the argument. There times that when you find a good article, the date does not fall under the given time period. (NS3)

Notably, students indicate that locating the right information could also be challenging because one must consider not only the relevance of the information but also their recency. This particular finding seems to differ from what they revealed in the quantitative result in which they reported low needs in considering time elements when conducting a literature review. Considering that they are nursing students, the qualitative finding is noteworthy due to the nature of nursing as a fast-paced and dynamic field.

\subsection{Academic Writing Needs of Nursing Students in Research}

In Table 3, a summary of the quantitative results regarding the academic writing needs of nursing students in research is presented. It can be deduced that nursing students' academic writing needs are moderate (WM: 2.99). Highest mean scores are obtained by Item Number 6, "I am confident to follow comments and 
suggestions" (MS: 3.56; SD: 0.60), Item Number 9, "I consult the dictionary or thesaurus to understand the words I use in my article" (MS: 3.56; SD: 0.50), and Item Number 10, "I strictly observe proper in-text and reference citations" (MS: 3.33; SD: 0.67). The lowest mean scores are those in the Item Number 4, "I write a paragraph free from grammatical errors" (MS: 2.50; SD: 0.69), Item Number 2, "I am aware of grammar rules" (MS: 2.61; SD: 0.83), Item Number 1, “I am aware of the various research formats to complete my article prior to journal submission" (MS: 2.67; SD: 0.94), and Item Number 3, "I am confident in my academic writing skills" (MS: 2.67; SD: 0.94).

Table 3: Academic Writing Needs of Nursing Students

\begin{tabular}{|l|l|l|l|}
\hline \multicolumn{1}{|l|}{ Items } & MS & SD & VI \\
\hline $\begin{array}{l}\text { 1. I am aware of the various research formats } \\
\text { to complete my article prior to journal } \\
\text { submission. }\end{array}$ & 2.67 & 0.94 & Moderate \\
\hline $\begin{array}{l}\text { 2. I am aware of grammar rules. } \\
\text { 3. I am confident in my technical writing skills. }\end{array}$ & 2.67 & 0.94 & Moderate \\
\hline $\begin{array}{l}4 . \quad \text { I write a paragraph free from grammatical } \\
\text { errors. }\end{array}$ & 2.50 & 0.69 & High \\
\hline $\begin{array}{l}\text { 5. I easily follow the guidelines set for } \\
\text { publication with minimal assistance from my } \\
\text { adviser. }\end{array}$ & 2.78 & 0.85 & Moderate \\
\hline $\begin{array}{l}\text { 6. I am confident to follow comments and } \\
\text { suggestions. }\end{array}$ & 3.56 & 0.60 & Low \\
\hline $\begin{array}{l}\text { 7. I read and re-read, and write and re-write } \\
\text { what I have initially read and written to keep } \\
\text { improvements of my article. }\end{array}$ & 3.22 & 0.79 & Moderate \\
\hline $\begin{array}{l}\text { 8. I know how to do proofreading and editing } \\
\text { of my own article. }\end{array}$ & 3.00 & 0.88 & Moderate \\
\hline $\begin{array}{l}\text { 9. I consult the dictionary or thesaurus to } \\
\text { understand the words I use in my article. }\end{array}$ & 3.56 & 0.50 & Low \\
\hline $\begin{array}{l}\text { 10. I strictly observe proper in-text and reference } \\
\text { citations. }\end{array}$ & 3.33 & 0.67 & Moderate \\
\hline Weighted Mean & 2.99 & 0.77 & Moderate \\
\hline
\end{tabular}

The quantitative result on students' academic writing needs, as illustrated above, implies that although in general, their academic writing needs are moderate, there is evidence that they may necessitate more support on English grammar for them to write effectively. This is illustrated in the lowest mean scores obtained in Items 4 and 2. While Item 4 is clear about writing free from grammatical errors, Item 2, I am aware of grammar rules means that students have metalinguistic knowledge such as knowledge on subject-verb agreement, active and passive voice, transitional devices, among others. 
As found in the quantitative result, nursing students need much support concerning these two aspects. Such a result is further elaborated in the qualitative responses of students, as exemplified in some extracts below.

I observed that grammar was also our weakness. We also had a hard time paraphrasing contents from the sources. An online grammar checker and paraphrasing tool was been helpful to us. (NS2)

This is also very challenging for me because I'm not really good in writing in any forms especially in English but I always tried and do my best to do the writings on my own and consulted some person I know that will help me to check on my grammar so that I can improve myself in writing English. (NS4)

We encountered countless of problems in terms of grammar, since we do not have the same proficiency or knowledge in doing so. It was such a critical aspect in research writing because good English writing skills are equal to better explanation of the topic. (NS5)

From the statements above, it can be inferred that the students need further knowledge of grammar rules, which seems to hinder them from writing a good research article in nursing. Given that English as a subject is required from elementary to tertiary level (Cam \& Tran, 2017), grammar is still of concern. However, NS2 and NS4 consider having some strategy in dealing with this problem by referring to specific online tools or by having a third person to do the language editing. Also, NS5 explicitly points out that knowledge of the English language is highly valuable. It aids in the production of a clear and concise explanation of one's ideas, which is needed in research writing. Moreover, nursing students' needs in academic writing are not limited to grammar. They also reported that skills in paraphrasing are fundamental. This is seen in NS2's response above, and this finding is consistent with the quantitative result.

Furthermore, because nursing research is highly technical and requires advanced academic writing skills, students state that the professional way of writing is essential. This specific finding agrees with what was found in the quantitative result, whereby students stated that they had moderate needs in adhering to guidelines set for publication as indicated by one of the lowest mean values from the dataset. This finding is further reflected in NS1's response below.

In writing in English, I think the biggest challenge for me is writing in professional English. Knowing myself, I tend to always write only in basic English. (NS1)

\section{Discussion}

This study aimed at investigating the academic reading and writing needs of nursing students in research. The quantitative results generally suggest that nursing students manifest moderate needs in terms of academic reading and writing. As supplemented by the qualitative findings, the overall analysis provides further evidence that these students do require as much support in terms of certain aspects of academic reading and writing. In their research, Chen, Khalid, and Faruk (2019) created a model to guide universities in adopting changes for the development of the academic writing skills of new scholars such 
as students which could lead to the advancement of the quality of research and publications globally.

Nursing students' academic literacy skills, such as academic reading and writing, have been espoused in previous studies (Borglin, 2012; Borglin \& Fagerström, 2012; Whitehead, 2002). On the aspect of academic reading, the results show that nursing learners need support concerning organizing literature items reviewed and synthesizing general concepts to generate a new idea. Given such findings, it appears that nursing students lack critical thinking in doing a literature review. The literature review is a critical component of research because it clarifies why students research the topic they investigated. Hence, nursing students should employ critical thinking in conducting a literature analysis. The ability to think critically is an integral aspect of medical nursing training (Mangena \& Chabeli, 2005; Profetto-McGrath, 2003). However, such skill is embedded when one reads at a critical level, especially when examining the literature review (Gile, 2001). Critical reading requires that students read research articles to critically evaluate their worth for "adequacy, appropriateness, and thoroughness" (Garrard, 2017). The findings on academic reading in this research support the study of Borglin (2012). It was asserted that the cultivation of skills in critical thinking and judgment is vital in nursing education. Undergraduate students' difficulty in reading research articles was also discovered in St Clair-Thompson, Graham, and Marsham's (2018) study.

As with academic writing, students' needs revolve around correct grammar, paraphrasing, adherence to a publication format, and confidence in academic writing. This means that nursing students may have little knowledge of the English language's grammatical structure, which consequently results in their difficulty in paraphrasing and, in general, in low confidence in academic writing. Students' needs on grammar were specifically indicated in the lowest mean scores of items in the quantitative survey relating to grammar rules. This particular result was also confirmed in the qualitative interview, where majority of the students reported challenges in terms of grammar rules. This finding corroborates Alfaki's (2015) study, which revealed the university students indicated several writing needs, mostly language-related at the levels of usage errors, mechanical mistakes, among others. This is also consistent with the result of Ratnawati, Faridah, Anam, and Retnaningdyah (2018) which found that Indonesian undergraduate students' academic writing needs were highly reflected in their use of incorrect grammar such as incorrect tenses. Grammatical competence, apart from vocabulary, is a fundamental linguistic device that every student, regardless of discipline, needs to develop to achieve proficiency in academic writing because students are expected to write in correct English (Coxhead, 2011). Thus, it can be argued that nursing students, despite their discipline as a hard science, should not be excused from developing good grammatical knowledge in English.

Additionally, it seems that nursing students, as far as the results of this study are concerned, are not genre-oriented. This is seen in their lack of awareness of the publication formats (Item 1 ) and their inability to comply with publication writing guidelines with minimal revisions (Item 5). However, this conclusion should be 
taken with careful consideration since students' needs were only self-reported, and a further probe delving into the students' actual writing when preparing to publish may be needed to confirm such result. Genre knowledge is equally essential in academic writing because it has been found to be strongly linked to students' writing performance (Graham, 2006; Lu, 2010). In this case, if nursing students are introduced to the language and conventions of academic writing in scientific publishing in their research class, then there is a prospect that they can become genre-oriented on publication writing. All these results on academic writing needs collectively corroborate Kapborg and Berterö's (2002) finding. It states that nursing students encounter problems relating to poor spelling and grammar, as well as inadequate structure. Moreover, previous studies (Diekelmann \& Ironside, 1998; Whitehead, 2002) also found a similar result in which nursing students demonstrate little knowledge upon which to build on, and the burden of addressing demanding and conventional academic writing needs which perhaps hindered the growth of inventive and authentic work.

Overall, this study provides further evidence endorsing the study of Borglin (2012), which suggested that the teaching of critical thinking and academic writing in nursing program has to take off from theoretically founded instructive models, e.g. academic literacies model by Lea and Street (1998, 2006). Indeed, research writing in nursing demands a multitude of academic literacies. Academic Reading and Writing are two of the most crucial skills that students ought to have to succeed in their writing endeavors.

\subsection{Implications for EAP Teaching}

Several pedagogical implications in the context of EAP can be drawn from the findings of the present study. First, language teachers, especially those teaching academic writing courses in higher education institutions, should explicitly teach different reading strategies that students can employ when doing a literature review. Explicit teaching of reading strategies can develop students' reading skills (Gatcho \& Hajan, 2019). By explicit teaching, it does not mean that teachers focus merely on theoretical aspects of reading strategies as a topic. Instead, they should guide the students on how to integrate such strategies into their real-life applications. In other words, these reading strategies, when taught to students, should enable them to develop critical thinking (Castillo-Hajan, Hajan \& Marasigan, 2019), which, in this case, can be achieved through a critical reading of the extensive works students examine as part of their literature review. To do this, language teachers should make use of published research articles within the students' discipline as reading materials.

It should be noted that literature review is an essential component of research as it involves students proving mastery in their field of discipline. It also provides justifications to the academic community about why students research their chosen topic. More importantly, critical reading is a vital precursor to critical writing (Knott, n.d.). Hence, it is indispensable that language teachers first develop students' academic reading skills before introducing them to the complexity of academic writing in research. 
Second, language teachers should teach academic writing to nursing students both at the micro and macro-level. At the micro-level, nursing students should be taught small bits of linguistic devices such as grammar, spelling, and punctuation. The teaching of these linguistic elements should be directly related to students' discipline because each discipline consists of its own bundle of lexical terms and structures (Hyland \& Tse, 2007). For example, whether students should use active voice rather than passive voice or vice versa in writing given their discipline has to be clearly explained to students. Nursing students should be taught genre, conventions, and styles in academic writing at the macro level, especially if the goal of nursing research is publication. Again, language teachers are suggested to make use of research articles published within the students' discipline as models for writing. By doing so, students can acquire the stylistic elements expected within the academic community of their field.

Third and last, because academic writing in the context of nursing research can be complex to teach, it would be best if language teachers are writers themselves. Language teachers, as writers, can have the advantage of being able to connect with students and understand their struggles in writing (Whitaker, 2012, as cited in, Hajan, Castillo-Hajan \& Marasigan, 2019). Hence, to help students boost their confidence in academic writing, language teachers must be not only knowledge dispensers but also motivators. Perhaps, motivating students in an academic writing classroom can best start with teachers sharing their written artifacts as models for student writing.

\subsection{Limitations of the Study}

Despite the pedagogical implications of the study, certain limitations are noted. The study has, by far, examined nursing students' academic reading and writing needs. Although employing mixed methods with both survey and interview data present, the investigation may have limitations in providing an actual view regarding nursing students since the study was heavily based on students' selfreported responses in its quantitative and qualitative phases. Self-reports may have failed to capture students' real needs as compared to when data collection involved analysis of students' actual writing, such as their research papers. In addition, the qualitative strand of the study may be unable to account for students' actual needs in academic reading and writing as no analysis of students' reading and writing skills based on their actual performance was made. Finally, considering the small sample size, the results of this study could not be generalizable to all nursing learners. Hence, conclusions about the nursing students' academic reading and writing needs have to be taken with careful consideration.

\section{Conclusion}

The study has attempted to investigate the academic reading and writing needs of nursing students in a research class. It was concluded that nursing students still need further support on their skills set on academic reading and writing for them to write in their chosen discipline successfully. In particular, they could hardly organize literature items reviewed and synthesize general concepts to formulate a new idea. This establishes that their academic reading needs principally revolve 
around organizing and synthesizing literature. Also, they have problems concerning the use of correct grammar, paraphrasing, adherence to a publication format, and confidence in academic writing. This illustrates that their complex academic writing needs range from foundational to more advanced skills in writing.

Building on the findings of this study, implications for EAP teaching were drawn suggesting that language teachers handling academic writing courses employ explicit teaching of reading strategies that facilitate critical reading, and teach academic writing both at the micro and macro levels, i.e., students taught small bits of linguistic resources as well as genre, convention, and style in academic writing. Pedagogical implications further explicate that it is best if language teachers of academic writing are writers themselves through which they can serve as motivators in boosting students' confidence in academic writing.

\subsection{Recommendations}

The study recommends that future research may employ language teachers who are teaching academic writing courses as respondents to gain more in-depth insights regarding students' academic reading and writing needs in nursing. This enables the triangulation of responses that can provide a more encompassing result. Besides, future studies may also consider investigating nursing students' research papers from a linguistic lens as basis for further explicating their needs in academic writing. For instance, genre analysis of their research introductions may help future researchers understand better students' academic writing skills in terms of organization and style. A more authentic tool for determining students' academic reading needs apart from the survey is also suggested. This is to address the limitations of self-reported responses of the participants captured by the self-administered questionnaire employed in the quantitative phase of this study. Furthermore, more nursing students sampled from different year levels are necessary for future research to provide a more conclusive view concerning academic reading and writing needs in nursing research.

\section{References}

Akcaoğlu, M. Ö. (2011). An assessment of academic writing needs of graduate students (Doctoral dissertation). Middle East Technical University.

Alfaki, I. M. (2015). University students' English writing problems: Diagnosis and remedy. International Journal of English Language Teaching, 3(3), 40-52.

Anito, J., \& Morales, M. P. (2019). The pedagogical model of Philippine steam education: drawing implications for the reengineering of Philippine STEAM learning ecosystem. Universal Journal of Educational Research, 7(12), 2662-2669. https://doi.org/10.13189/ujer.2019.071213

Anito, J., Limjap, A., \& Padagas, R. (2020). Praxis for accelerated improvement in research (PAIR). International Journal of Higher Education, 9(3), 248-261. https:// doi.org/10.5430/ijhe.v9n3p248

Bhatia, V. K. (1993). Analyzing genre: Language use in professional settings. London: Longman.

Borgers, N., Sikkel, D., \& Hox, J. (2004). Response effects in surveys on children and adolescents: The effect of number of response options, negative wording, and neutral midpoint. Quality and Quantity, 38(1), 17-33. 
Borglin, G. (2012). Promoting critical thinking and academic writing skills in nurse education. Nurse Education Today, 32(5), 611-613. https://doi.org/10.1016/j.nedt.2011.06.009

Borglin, G., \& Fagerström, C. (2012). Nursing students' understanding of critical thinking and appraisal and academic writing: A descriptive, qualitative study. Nurse Education in Practice, 12(6), 356-360. https:// doi.org/10.1016/j.nepr.2012.04.009

Cam, L., \& Tran, T. T. M. (2017). An Evaluation of using Games in Teaching English Grammar for First Year English-Majored Students at Dong Nai Technology University. International Journal of Learning, Teaching and Educational Research, 16(7), 55-71.

Carrell, P. L. (1985). Facilitating ESL reading by teaching text structure. TESOL Quarterly, 19, 727-752. https://doi.org/10.2307/3586673

Castillo-Hajan, B., Hajan, B. H., \& Marasigan, A. C. (2019). Construction of second language writer identity in student persuasive essays: A metadiscourse analysis. The Asian EFL Journal, 21(2.3), 36-60.

Chen, C., Khalid, H., \& Amin, F. R. (2017). Advanced Academic Writing Course for International Students Belonging to "One Belt, One Road." International Journal of Learning, Teaching and Educational Research, 16(10), 90-99. https://doi.org/10.26803/ ijlter.16.10.7

Commission on Higher Education (2017). Policies, standards and guidelines for the Bachelor of Nursing (BSN) program. Retrieved from https://ched.gov.ph/wpcontent/uploads/2017/10/CMO-15-s-2017.pdf.

Coxhead, A. (2011). The academic word list 10 years on: Research and teaching implications. TESOL Quarterly, 45(2), 355-362. https:// doi.org/10.5054/tq.2011.254528

Cresswell, J. W. \& Plano-Clark, V. L. (2011). Designing and conducting mixed method research ( $2^{\text {nd }}$ ed.). London: Sage Publication Ltd.

Derouin, A. L., Hueckel, R. M., Turner, K. M., Hawks, S. J., Leonardelli, A. K., \& Oermann, M. H. (2015). Use of workshops to develop nurses' and nursing students' writing skills. The Journal of Continuing Education in Nursing, 46(8), 364-369. https://doi.org/10.3928/00220124-20150721-03

Diekelmann, N., \& Ironside, P. M. (1998). Preserving writing in doctoral education: Exploring the concernful practices of schooling learning teaching. Journal of Advanced Nursing, 28, 1347-1355. https:// doi.org/10.1046/j.1365-2648.1998.00819.x

Faizah, A. M. (2004). Adult learners characteristics and their academic reading strategies: A case study (PhD Thesis). Universiti Kebangsaan Malaysia.

Garrard, J. (2017). Health sciences literature review made easy: The matrix method. Burlington, MA: Jones \& Bartlett Learning.

Gatcho, A. R. G., \& Hajan, B. H. (2019). Augmenting senior secondary ESL learners' reading skills through explicit instruction of metacognitive strategies. Journal of English Education and Linguistics Studies, 6(1), 1-24. https://doi.org/10.30762/jeels.v6i1.1202

Gazza, E. A., \& Hunker, D. F. (2012). Facilitating scholarly writer development: The writing scaffold. Nursing Forum, 47(4), 278-285. https://doi.org/10.1111/j.17446198.2012.00275.x

Gile, D. (2001). Critical reading in (interpretation) research. In D. Gile, D. Helle, D. Friedel, M. Bodil \& A. Schjoldager (Eds). 2001. Getting Started in Interpreting Research, pp. 2338. Amsterdam/Philadelphia: John Benjamins.

Graham, S. (2006). Writing. In P. A. Alexander \& P. H. Winne (Eds.), Handbook of educational psychology, pp. 457-478. Mahwah, NJ: Erlbaum.

Grami, G. M. A. (2010). The effects of integrating peer feedback into university-level ESL writing curriculum: A comparative study in a Saudi context (Doctoral dissertation). Newcastle 
University, School of Education, Communication and Language Sciences. Retrieved from https://theses.ncl.ac.uk/dspace/bitstream/10443/933/1/grami_

Gutierrez, R., \& Padagas, R. (2019). Unveiling a painpoint in a college classroom: College students' perceptions of academic dishonesty and some tests of correlations. Universal Journal of Educational Research, 7(12), 2634-2641. https://doi.org/10.13189/ujer.2019.071210.

Hajan, B. H., Castillo-Hajan, B., \& Marasigan, A. C. (2019). Second language academic writing: A study of teachers' beliefs and pedagogical practices in senor high school. The Asian EFL Journal, 21(2.3), 9-35.

Harwood, N., \& Hadley, G. (2004). Demystifying institutional practices: Critical pragmatism and the teaching of academic writing. English for Specific Purposes, 23(4), 355-377. https://doi.org/10.1016/j.esp.2003.08.001

Hyland, K., \& Tse, P. (2007). Is there an "academic vocabulary"? TESOL Quarterly, 41(2), 235-253. https://doi.org/10.1002/j.1545-7249.2007.tb00058.x

Hyon, S. (2001). Long-term effects of genre-based instruction: a follow-up study of an EAP reading course. ESP, 20, 417-438. https://doi.org/10.1016/s0889-4906(01)00019-9

Hyland, Ken. (2003). Second language writing. Cambridge. New York: Cambridge University Press.

Kapborg, I., \& Berterö, C. (2002). Critiquing bachelor candidates' theses: Are the criteria useful? International Nursing Review, 49, 122-128. https://doi.org/10.1046/j.14667657.2002.00123.x

Knott, D. (n.d.). Critical reading toward critical writing. University of Toronto Writing Advice. Retrieved from https://advice.writing.utoronto.ca/wpcontent/uploads/sites/2/critical-reading.pdf

Knowles, J., \& McGloin, S. (2007). Developing critical analysis skills in academic writing. Nursing Standard, 21(52), 35-37. https:// doi.org/10.7748/ns.21.52.35.s48

Levine, A., Ferenz, O., \& Reves, T. (2000). EFL Academic reading and modern technology: How can we turn our students into independent critical readers? TESL-EJ, 4(4).

Leung, S. O. (2011). A comparison of psychometric properties and normality in 4-, 5-, 6-, and 11-point Likert scales. Journal of Social Service Research, 37(4), 412-421.

Lu, Y. (2010). Cognitive factors contributing to Chinese EFL learners' L2 writing performance in timed essay writing (Dissertation). Georgia State University.

Mangena, A. \& Chabeli, M. M. (2005). Strategies to overcome obstacles in the facilitation of critical thinking in nursing education. Nurse Education Today, 25, 291-298. https://doi.org/10.1016/j.nedt.2005.01.012

Miller, L. C., Russell, C. L., Cheng, A., \& Skarbek, A. J. (2015). Evaluating undergraduate nursing students' self-efficacy and competence in writing: Effects of a writing intensive intervention. Nurse Education in Practice, 15(3), 174-180. https://doi.org/10.1016/j.nepr.2014.12.002

Miller, L. C., Russell, C. L., Cheng, A.-L., \& Zembles, S. (2018). Testing the efficacy of a scaffolded writing intervention with online degree-completion nursing students: A quasi-experimental design. Nurse Education in Practice. https:// doi.org/10.1016/j.nepr.2018.06.011

O'Brien, T., \& Hathaway, D. (2018). Students and faculty perceptions of an undergraduate nursing research internship program. Nurse Educator, 43(2), E1-E4. https:// doi.org/10.1097/nne.0000000000000412

Padagas, R. C. (2020). How to overcome learning challenges in a biochemistry class? Uncovering lessons from facilitation styles and collaborative learning. International Journal of Scientific and Technology Research, 9(2), 3776-3782. 
Parilo, D. W., Parsh, B., \& Sampson, J. (2019). Nursing student-faculty writing partnerships at the baccalaureate level: Research brief. Nursing Forum, 54(3), 410-413. https://doi.org/10.1111/nuf.12348

Profetto-McGrath, J. (2003). The relationship of critical thinking skills and critical disposition of baccalaureate nursing students. Journal of Advanced Nursing, 43(6), 569-577. https:/ / doi.org/10.1046/j.1365-2648.2003.02755.x

Ratnawati, R., Faridah, D., Anam, S., \& Retnaningdyah, P. (2018). Exploring Academic Writing Needs of Indonesian EFL Undergraduate Students. Arab World English Journal, 9(4), 420-432. https://dx.doi.org/10.24093/awej/vo19no4.31

Ryan, E. J. (2016). Baccalaureate nursing students' attitudes and use of research and evidence-based practice-an integrative literature review. Journal of Clinical Nursing, 25(11-12), 1548-1556. https://doi.org/10.1111/jocn.13229

Schleppegrell, M. (2012). Academic language in teaching and learning. Elementary School Journal, 112(3), 409-418. https://doi.org/10.1086/663297

Sengupta, S. (2002). Developing academic reading at the tertiary level: A longitudinal study of tracing conceptual change. The Reading Matrix, 2(1). Retrieved from http://www.readingmatrix.com/articles/sengupta/article.pdf

Shellenbarger, T., Gazza, E. A., \& Hunker, D. F. (2018). Advancing scholarly writing of baccalaureate nursing students using the knowledge, skills, and attitude selfassessment for writing development. Nurse Education Today, 69, 109112. https://doi.org/10.1016/j.nedt.2018.07.006

St Clair-Thompson, H., Graham, A., \& Marsham, S. (2018). Exploring the reading practices of undergraduate students. Education Inquiry, 9, 284-298. https://doi.org/10.1080/20004508.2017.1380487

Szyba, C., Didry, P., Kaltenbach, A., Phulpin, S., Schuster, P., \& Zieleniewicz, M. L. (2018). Initiation à la culture de recherche auprès des étudiants en soins infirmiers en formation initiale : état des lieux dans les ifsi lorrains. Recherche En Soins Infirmiers, 134(3), 52-59. https:// doi.org/10.3917/rsi.134.0052

Tai, H., Pan, M., \& Lee, B. (2016). Effects of attributional retraining on writing performance and perceived competence of Taiwanese university nursing students. Nurse Education Today, 44, 66-73. https://doi.org/10.1016/j.nedt.2016.05.008

Tanhueco-Tumapon, T. (2016, March 10). Service-learning in higher education. The Manila Times. Retrieved from https://www.manilatimes.net/2016/ 03/10/opinion/columnists/service-learning-in-higher-education/249721/

Uysal Toraman, A., Hamaratçllar, G., Tülü, B., \& Erkin, Ö. (2017). Nursing students' attitudes toward research and development within nursing: Does writing a bachelor thesis make a difference? International Journal of Nursing Practice, 23(2), e12517. https:// doi.org/10.1111/ijn.12517

Wa-Mbaleka, S. (2014). Teaching English to speakers of other langauges: The case of Philippines. International Journal of Academic Research in Progressive Education and Development, 3(3), 64-78. https:// doi.org/10.6007/IJARPED/v3-i3/952

Whitehead, D. (2002). The academic writing experience of a group of nursing students: a phenomenological study. Journal of Advanced Nursing, 38(5), 498-506. https:// doi.org/10.1046/j.1365-2648.2002.02211.x

Yancey, N. R. (2016). The challenge of writing for publication. Nursing Science Quarterly, 29(4), 277-282. https:// doi.org/10.1177/0894318416662931 